Огляди літератури, оригінальні дослідження, погляд на проблему, випадок з практики, короткі повідомлення УДК 612.017.1-01:616.935-036.11

DOI 10.11603/1811-2471.2020.v.i1.10857

\title{
ВАРІАБЕЛЬНІСТЬ ІМУНОЛОГІЧНИХ ПОКАЗНИКІВ У ХВОРИХ НА ГОСТРУ ДИЗЕНТЕРІЮ
}

\author{
๑В. П. Борак, Л. Б. Романюк, Н. Я. Кравець, В. Т. Борак, І. І. Медвідь, І. М. Галабіцька
}

Тернопільський національний медичний університет імені І. Я. Горбачевського МОЗ України

РЕЗЮмЕ. У структурі інфекційної захворюваності кишкові інфекції займають друге місце після респіраторних хвороб. 3 декількох причин шигельоз (дизентерія) займає серед них провідне місце. За даними різних джерел, серед етіологічно верифікованих діарей вона складає від 28 до 75 \%. Одним із ефективних та достовірних показників підтвердження діагнозу при дизентерії $\epsilon$ імунологічне дослідження для виявлення змін клітинної ланки імунітету та специфічних антитіл.

Мета - вивчити та проаналізувати зміни клітинної та гуморальної ланок імунітету, що виникають у хворих на дизентерію.

Матеріал і методи. Було обстежено 30 пацієнтів із гострим шигельозом, які перебували на лікуванні в інфекційному відділені Міської комунальної лікарні № 1. Загальну кількість Т-лімфоцитів, В-лімфоцитів визначали за допомогою реакції спонтанного розеткоутворення (ЕАС-РУЛ, ТЕ-РУЛ). Функціональну активність Т-лімфоцитів оцінювали за реакцією бластної трансформації Т-лімфоцитів з фітогемаглютиніном. Рівні IgM, IgA та IgG визначали за методом Манчіні.

Результати. У віковому аспекті обстежений контингент складався із хворих у віці 23-59 років - 21 (70,0 \%) особа, 60 років і старше - 9 (30,0 \%) осіб. Серед обстежених 30 пацієнтів з гострим шигельозом 10 мали легкий перебіг, 13 - середнього ступеня тяжкості, 7 - тяжкий перебіг. Імунорегуляторний індекс при легкому ступені хвороби, викликаної S. Soпnеi, варіював від 2,12 до 3,18, при середньотяжкому - 2,45-4,82, при тяжкому - 1,80-5,25. Показники імунорегуляторного індексу у пацієнтів з виділеною S. fехпегі при легкому ступені складали 2,03-2,81; при середньому - 3,32-3,96; при тяжкому - 2,02-4,07.

Висновки. Дослідження імунологічних показників у гострому періоді хвороби виявили зміни лише при середньому та тяжкому ступенях дизентерії. 3 боку гуморального імунітету суттєвих відмінностей у реакції хворих на дизентерію залежно від віку не було.

КЛючОВІ СЛОВА: гостра дизентерія; гуморальний імунітет.

Вступ. У структурі інфекційної захворюваності кишкові інфекції займають друге місце після респіраторних хвороб. 3 декількох причин шигельоз (дизентерія) займає серед них провідне місце. За даними різних джерел, серед етіологічно верифікованих діарей вона складає від 28 до $75 \%[1,4]$. Цю «хворобу брудних рук» прийнято вважати дитячою інфекцією, у країнах Латинської Америки, Африки і Азії її вважають однією з основних причин смертності дітей до 5-річного віку. Такий великий розмах відсотків захворюваності можна пояснити двома причинами: по-перше, виділення шигел $\epsilon$ досить складним і копітким процесом, що вимагає дотримання суворих правил при заборі матеріалу та проведенні бактеріологічного дослідження, i, як наслідок, - отримати шигели в чистій культурі вдається у 25-50 \% випадків; подруге, клінічний перебіг, етіотропне та симптоматичне лікування інфекційних діарей бактеріального походження практично не відрізняється, тому на амбулаторному етапі, як правило, бактеріологічне дослідження проводять досить рідко.

Результати й обговорення. Одним із ефективних та достовірних показників підтвердження діагнозу при дизентерії $\epsilon$ імунологічне дослідження для виявлення змін клітинної ланки імунітету та специфічних антитіл. Однак цей метод доступний в основному для ретроспективної діагностики шигельозу, та для оцінки епідемічної ситуації.

Метою нашого дослідження було вивчити та проаналізувати зміни клітинної та гуморальної ланок імунітету, які виникають у хворих на дизентерію.

Матеріал і методи дослідження. Обстежено 30 пацієнтів із гострим шигельозом, які перебували на лікуванні в інфекційному відділені Міської комунальної лікарні № 1. Показники, які брали до уваги при оцінці імунного статусу, були наступними: визначення кількості Т-лімфоцитів, Т-хелперів, Т-супресорів, їх субпопуляцій, імунорегуляторний індекс (CD4+/CD8+), кількість В-лімфоцитів, рівні IgM, IgA та IgG. Крім того, проводили стандартне бактеріологічне дослідження з видовою ідентифікацією шигел.

у стабілізованій крові визначали загальну кількість Т-лімфоцитів (ТЕ-РУЛ) - у реакції спонтанного розеткоутворення з еритроцитами вівці, їх субпопуляції - Т-хелпери; кількість "активних»; кількість Т-лімфоцитів з переважно супресорною активністю (Тs-РУЛ) - шляхом віднімання числа теофілінрезистентних Т-клітин (ТФР) від загальної кількості Т-лімфоцитів, В-лімфоцити (ЕАС-РУЛ) -у реакції комплементарного розеткоутворення 3 еритроцитами вівці. При підрахунку кількості Т- і 
Огляди літератури, оригінальні дослідження, погляд на проблему, випадок з практики, короткі повідомлення В-лімфоцитів та їх регуляторних субпопуляцій на фіксованих і фарбованих мазках крові визначали лімфоцити із низькою (3-5) і середньою (6-10) щільністю рецепторів та функціонально недиференційовані лімфоцити (0). Функціональну активність Т-лімфоцитів оцінювали за реакцією бластної трансформації Т-лімфоцитів з фітогемаглютиніном [6]. Рівні IgM, IgA та IgG визначали за методом Манчіні. Усі пацієнти давали інформовану згоду на участь у дослідженні. Отримані цифрові дані опрацьовували із застосуванням пара-

метричних і непараметричних методів статистики за допомогою програмного забезпечення

Результати й обговорення. У віковому аспекті обстежений контингент складався із хворих у віці 23-59 років - 21 особа (70,0 \%), 60 років і старше - 9 (30,0 \%) осіб, що є важливим з огляду на різні функціональні особливості імунної системи у осіб різного віку. Серед обстежених 30 пацієнтів з гострим шигельозом 10 мали перебіг легкого ступеня, 13 - середнього ступеня тяжкості, 7 - тяжкий (рис. 1).

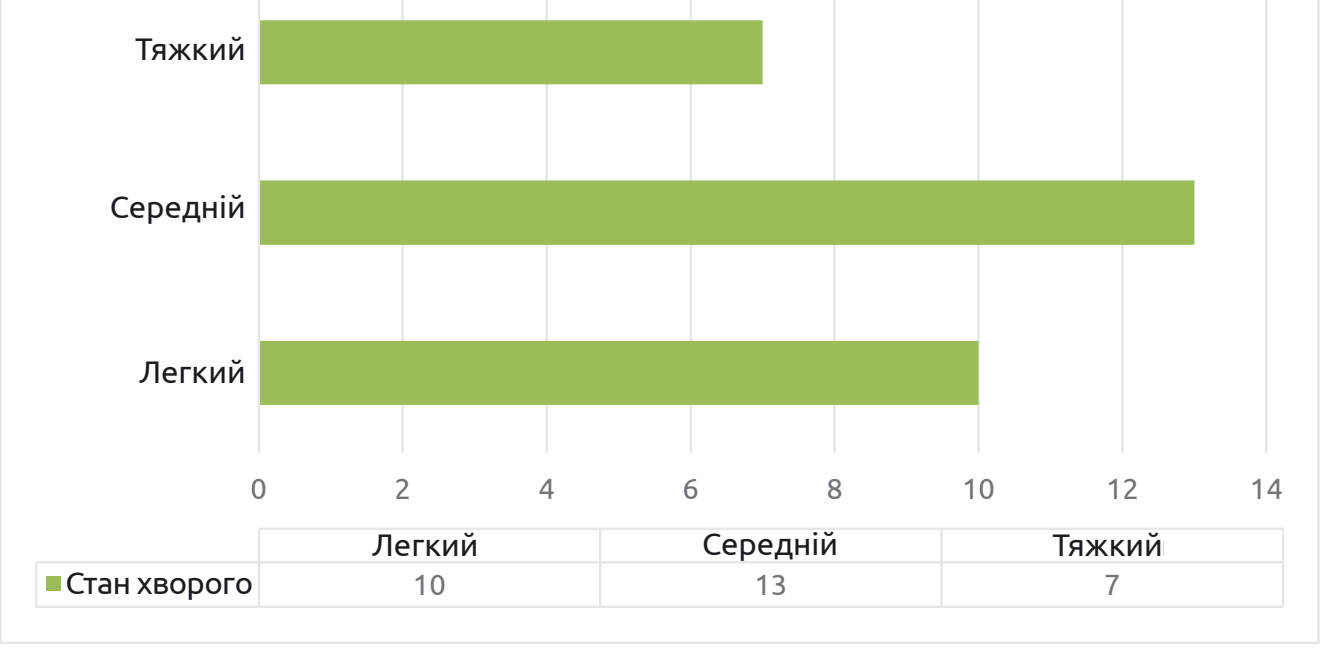

Рис. 1. Вікова структура досліджуваних пацієнтів.

При дослідженні імунологічних показників у гострому періоді хвороби зміни виявлені лише при середньому та тяжкому ступенях дизентерії. Відмічалось достовірне ( $<<0,05)$ зниження кількості Т-хелперів та Т-супресорів. Також виявлено затримку і порушення у диференціації лімфоцитів при дизентерії, викликаній S. sonnei: частота виявлення нульових та недиференційованих Т-клітин була більшою, порівняно зі здоровими особами: при середньому ступені тяжкості - $(40,0 \pm$ $2,05) \% ;$ при тяжкому - $(53,2 \pm 2,01) \%$, паралельно 3 цим відмічався приріст кількості «активних» Т-клітин. Імунорегуляторний індекс при легкому ступені хвороби варіював від 2,12 до 3,18, при середньотяжкому - 2,45-4,82, при тяжкому - 1,805,25. У періоді реконвалесценції (2 тиждень захворювання) рівень загальних Т-лімфоцитів нормалізувався при дизентерії, викликаній S. sonnei, а при підтвердженій S. flexneri - не досягав рівня здорових осіб. Кількість Т-супресорів при цьому залишалась низькою у всіх реконвалесцентів, незалежно від етології захворювання. Показники імунорегуляторного індексу при цьому дещо знизились: при легкому ступені - 2,03-2, 81; при середньому - 3,32-3,96; при тяжкому - 2,02-4,07.
Кількість нульових лімфоцитів достовірно зменшилась, причому в осіб із середнім ступенем важкості вона наближалась до норми, а при тяжкому - значно перевищувала показники у здорових осіб ( $p<0,05-0,01)$.

Гуморальну ланку оцінювали за кількістю В-лімфоцитів та імуноглобулінів. У гострій фазі дизентерії кількість В-лімфоцитів значно зменшилась, однак у період реконвалесценції цей показник повертався до норми у всіх категорій обстежених хворих. Рівні IgA залежно від стадій шигельозу не змінювались, а рівні IgM та IgG були помірно підвищеними, порівняно із нормальними показниками, але, оскільки вони є маркерами первинної імунної відповіді, то така динаміка $є$ закономірною для інфекцій бактеріальної етіології. Цікавим $\epsilon$ те, що у реконвалесцентів дизентерії, викликаної S. flexneri, рівень IgM залишався підвищеним протягом всієї хвороби.

Динаміка показників імунітету в пацієнтів, хворих на шигельоз, у віці старше за 60 років, не відрізнялась від аналогічного показника пацієнтів молодшого віку, однак кількість Т-лімфоцитів у них перевищувала норму навіть у період реконвалесценції. 3 боку гуморального імунітету суттє- 
Огляди літератури, оригінальні дослідження, погляд на проблему, випадок з практики, короткі повідомлення вих відмінностей у реакції хворих на дизентерію залежно від віку не було.

Висновки. Патогенетичні механізми, що призводять до розвитку клінічних симптомокомплексів при дизентерії, впливають на стан імунної системи організму хворого, не залежно від його віку, та від стану перебігу захворювання, зокрема у гострому періоді хвороби констатували зміни лише при середньому та тяжкому ступенях дизентерії. Імунорегуляторний індекс при легкому ступені хвороби, викликаної S. sonnei, варіював від 2,12 до 3,18, при середньотяжкому - 2,454,82, при тяжкому - 1,80-5,25. Показники імуно-

регуляторного індексу в пацієнтів із виділеною S. flexneri склав при легкому ступені - 2,03-2,81; при середньому - 3,32-3,96; при тяжкому - 2,024,07.

Можна стверджувати, що при гострому шигельозі розвивається вторинний імунодефіцит, але його характеристики залежать від збудника, котрий викликає захворювання, тяжкості перебігу дизентерії, очевидно, наявності супутньої патології. Більш вираженими є зміни з боку клітинної ланки імунітету, тоді як гуморальна задіяна менш активно, однак, якщо зміни виникають, то вони залишаються на тривалий час.

\title{
ЛІТЕРАТУРА
}

1. Алгоритми диференційної діагностики та лікування гострих кишкових інфекцій у дітей : навч.-метод. посіб. / О. В. Усачова, Є. А. Сіліна, Т. М. Пахольчук [та ін.]. - Запоріжжя : ЗДМУ, 2015-103 с.

2. Андрейчин М. А. Шигельоз / М. А. Андрейчин, В. М. Козько, В. С. Копча. - Тернопіль : Укрмедкнига, 2002. $-361 \mathrm{C}$.

3. Казмірчук В. Є. Клінічна імунологія та алергологія / В. Є. Казмірчук, Л. В. Ковальчук. - Вінниця : Нова книга, 2006. -526 с.

\section{REFERENCES}

1. Usachova, O.V., Silina, Ye.A., \& Pakholchuk, T.M. (2015). Alhorytmy dyferentsinoi diahnostyky ta likuvannia hostrykh kyshkovykh infektsii u ditei: navch.-metod. posib. [Algorithms for differential diagnosis and treatment of acute intestinal infections in children: a teaching manual]. Zaporizhzhia: ZDMU [in Ukrainian]

2. Andreichyn, M.A., Kozko, V.M., Kopcha, V.S. (2002). Shyheloz. [Shigelloz]. Ternopil: "Ukrmedknyha” [in Ukrainian]

3. Kazmirchuk, V.Ye., \& Kovalchuk, L.V. (2006). Klinichna imunolohiia ta alerholohiia [Clinical immunology and allergology]. Vinnytsia: Nova Knyha [in Ukrainian].

4. Kazmirchuk, V.Ye. (2007). Interprytatsiia leikohramy ta imunohramy zhidno z sushasnymy pozytsiiamy [In-

terpretation of leukograms and immunograms according to the suction position]. Vnutrishnia medytsyna - Internal Medicine, 4(4), 12-26 [in Ukrainian]

5. Shyrobokov, V.P. (Ed.). (2010). Medychna mikrobiolohiia, virusolohiia ta imunolohiia [Medical microbiology, virology and immunology]. Vinnytsia: Nova knyha [in Ukrainian]

6. Mudrak, D.I., \& Vishchur, O.I. (2011). Kilkist T-i V- limfotsytiv ta yikh funktsionalna aktyvnist u krovi husey za riznoho rivnia vitaminiv E i C u ratsioni [Quantity of T - and $B$ lymphocytes and their functional activity in goose blood at different levels of vitamins $\mathrm{E}$ and $\mathrm{C}$ in the diet]. Biolohiia tvaryn - Biology of Animals, 13 (1-2), 427-231 [in Ukrainian].

\section{ВАРИАБЕЛЬНОСТЬ ИММУНОЛОГИЧЕСКИХ ПОКАЗАТЕЛЕЙ У БОЛЬНЫХ ОСТРОЙ ДИЗЕНТЕРИЕЙ}

\author{
○В. П. Борак, Л. Б. Романюк, Н. Я. Кравец, В. Т. Борак, И. И. Медвидь, И. М. Галабицкая
}

Тернопольский национальный медицинский университет имени И. Я. Горбачевского МОз Украины

РЕЗЮМЕ. В структуре инфекционной заболеваемости кишечные инфекции занимают второе место после респираторных болезней. По нескольким причинам шигеллез (дизентерия) занимает среди них ведущее место. По данным различных источников, среди этиологически верифицированных диарей она составляет от 28 до 75 \%. Одним из эффективных и достоверных показателей подтверждения диагноза при дизентерии является иммунологическое исследование для выявления изменений клеточного звена иммунитета и специфических антител. 
Огляди літератури, оригінальні дослідження, погляд на проблему, випадок з практики, короткі повідомлення

Цель - изучить и проанализировать изменения клеточного и гуморального звеньев иммунитета, возникающие у больных дизентерией.

Материал и методы. Было обследовано 30 пациентов с острым шигеллезом, находившихся на лечении в инфекционном отделении Городской коммунальной больницы №1. Общее количество Т-лимфоцитов, В-лимфоцитов определяли с помощью реакции спонтанного розеткообразования (ТО-рул, ЕАС-рул). Функциональную активность Т-лимфоцитов оценивали с помощью реакции бластной трансформации Т-лимфоцитов с фитогемаглютинином. Уровень IgM, IgA и IgG определяли за методом Манчини.

Результаты. В возрастном аспекте обследованный контингент состоял из больных в возрасте 23-59 лет 21 (70,0\%) больной, 60 лет и старше - 9 (30,0\%) пациентов. Среди обследованных 30 пациентов с острым шигеллезом 10 имели легкое течение, 13 - средней степени тяжести, 7 - тяжелое течение. Иммунорегуляторный индекс при легкой степени болезни, вызванной S. sonnei, варьировал от 2,12 до 3,18, при среднетяжелом - 2,45-4,82, при тяжелом - 1,80-5,25. Показатели иммунорегуляторного индекса у пациентов с выделенной S. fexnегі при легкой степени составляли 2,03-2,81; при средней - 3,32-3,96; при тяжелой - 2,02-4,07.

Выводы. Исследования иммунологических показателей в остром периоде болезни обнаружили изменения только при средней и тяжелой степени дизентерии. Со стороны гуморального иммунитета существенных различий в реакции больных дизентерией в зависимости от возраста не было.

КЛЮЧЕВЫЕ СЛОВА: острая дизентерия; гуморальныЙ иммунитет.

\section{VARIABILITY OF IMMUNOLOGICAL INDICES IN PATIENTS WITH ACUTE DYSENTERIA ○V. P. Borak, L. B. Romanyuk, N. Y. Kravets, V. T. Borak, I. I. Medvid, I. M. Halabitska I. Horbachevsky Ternopil National Medical University}

SUMMARY. In the structure of infectious morbidity intestinal infections occupy the second place after respiratory diseases. For several reasons, shigellosis (dysentery) occupies a leading position among them. According to various sources, among etiologically verified diarrhea, it ranges from 28 to $75 \%$. One of the effective and reliable indicators of confirmation of diagnosis in dysentery is an immunological examination to detect changes in the cellular level of immunity and specific antibodies.

The aim of our research was to study and analyze the changes in cellular and humoral immunity that occur in patients with dysentery.

Material and Methods. Thirty patients with acute shigellosis who were in the infectious ward of City Public Hospital No. 1 were examined. The total number of T-lymphocytes, B-lymphocytes by the reaction of spontaneous rosette formation (EAS-RUL, TE-RUL) was determined. The functional activity of T-lymphocytes was evaluated by the reaction of blast transformation of T-lymphocytes with phytohemagglutinin. The IgM, IgA and IgG levels were determined by the Mancini method.

Results and Discussion. In terms of age, the surveyed contingent consisted of patients aged 23-59 years - 21 people $(70.0 \%), 60$ years and older -9 (30.0\%). Among the examined 30 patients with acute shigellosis, 10 had a mild course, 13 had a moderate severity, and 7 had a severe one. The immunoregulatory index for mild disease caused by S. sonnei varied from 2.12 to 3.18 , with moderate $-2.45-4.82$, and severe $-1.80-5.25$. Indicators of immunoregulatory index in patients with isolated S. fexneri was at a slight degree -2.03-2.81; at an average of 3.32-3.96; in severe - 2.02-4.07.

Conclusions. Studies of immunological parameters in the acute period of the disease found changes only with moderate and severe dysentery. There were no significant differences in humoral immunity in patients with dysentery depending on age.

KEY WORDS: acute dysentery; humoral immunity. 